\title{
TRANSFER IDEI Z BIOLOGII DO INFORMATYKI NA PRZYKŁADZIE ALGORYTMÓW EWOLUCYJNYCH
}

\begin{abstract}
Streszczenie. Informatycy zajmujący się problematyką algorytmów ewolucyjnych twierdzą, że miał miejsce transfer idei z biologii do informatyki, tzn. że ustalenia biologii ewolucyjnej stały się inspiracją do powstania tych algorytmów i że działają one analogicznie do procesów ewolucyjnych zachodzących w świecie przyrody. Jeśli jest tak faktycznie, to warto odpowiedzieć na pytanie, w jakim zakresie następuje przeniesienie ustaleń z biologii ewolucyjnej do działu informatyki zajmującego się algorytmami ewolucyjnymi. Zadanie to stanie się możliwe po uprzednim zreferowaniu sposobu działania algorytmów ewolucyjnych.
\end{abstract}

Słowa kluczowe: filozofia informatyki, sztuczna inteligencja, ewolucjonizm, biologia ewolucyjna, algorytmy ewolucyjne

1. Wprowadzenie. 2. Algorytmy ewolucyjne. 3. Podstawowe idee biologii ewolucyjnej zaimplementowane w algorytmach ewolucyjnych. 4. Podsumowanie.

\section{WPROWADZENIE}

Darwinowska teoria ewolucji była i jest stosowana nie tylko do wyjaśniania adaptacji organizmów żywych. Używa się jej również do proponowania rozwiązań i konceptualizacji problemów dotyczących ${ }^{1}$ : źródeł systemów moralnych, powstawania życia, zdolności rozumowania, źródeł rozwoju kultury, zachowań społeczności uczonych i zmiany systemów konceptualnych oraz zagadnień epistemologicznych $^{2}$. W drugiej połowie XX wieku biologia ewolucyjna zaczęła inspirować także informatyków poszukujących nowych sposobów

1 Por. M. Czarnocka, Podmiot poznania a nauka, Toruń 2012, 75-76.

2 Por. S. Leciejewski, Ewolucyjna teoria epistemologiczna metodą algorytmów genetycznych, Przegląd Filozoficzny - Nowa Seria 23(2014)4(92), 262-273. 
rozwiązywania problemów obliczeniowych i optymalizacyjnych, co doprowadziło do powstania algorytmów ewolucyjnych ${ }^{3}$. Cieszą się one sporym zainteresowaniem $\mathrm{z}$ powodu prostego schematu oraz licznych zastosowań praktycznych w różnych dziedzinach ${ }^{4}$.

Informatycy zajmujący się problematyką algorytmów ewolucyjnych twierdzą, że w „,iągu ostatnich (...) lat narastało zainteresowanie systemami, w których do rozwiązywania zadań stosuje się zasady ewolucji i dziedziczności. W systemach tych występuje populacja potencjalnych rozwiązań, zawierają one pewien proces selekcji, oparty na dopasowaniu osobników, i pewne operatory "genetyczne«. Jednym $z$ typów takich systemów jest klasa strategii ewolucyjnych, to znaczy algorytmów, które naśladują zasady ewolucji w naturze przy rozwiązywaniu zadań optymalizacji parametrycznej”’.

W swoim artykule prześledzę, czy ten deklarowany przez informatyków, zajmujących się algorytmami ewolucyjnymi, transfer idei z biologii do informatyki faktycznie miał miejsce. Jeśli tak jest, to postaram się także odpowiedzieć na pytanie, w jakim zakresie następuje przeniesienie ustaleń z biologii ewolucyjnej do działu informatyki zajmującego się algorytmami ewolucyjnymi. Zadanie to stanie się możliwe po uprzednim zreferowaniu sposobu działania algorytmów ewolucyjnych.

3 Syntetyczne omówienie genezy, historii i rozwoju algorytmów genetycznych znaleźć można w: J. Arabas, Wykłady z algorytmów ewolucyjnych, Warszawa 2004, 17-19.

4 Algorytmy ewolucyjne znajdują zastosowania m.in.: w oprogramowaniu wspomagającym projektowanie (CAD), w elektronice do projektowania rozłożenia elementów na płytce krzemowej, w radiotechnice do projektowania anten, w optymalizacji kolejności dostarczania przesyłek, w harmonogramowaniu zadań, we wspomaganiu nawigacji, w planowaniu tras robotów, jako narzędzie wspomagania decyzji, w sztucznej inteligencji i maszynowym uczeniu, gdzie np. poszukuje się optymalnych reguł klasyfikacji opisujących dostępne dane. Por. J. Arabas, dz. cyt., 19-21.

5 Z. Michalewicz, Algorytmy genetyczne + struktury danych = programy ewolucyjne, Warszawa 1999, 25. 


\section{ALGORYTMY EWOLUCYJNE}

Jednymi z głównych grup problemów ontologicznych i epistemologicznych zaliczanych do filozofii informatyki są te, które pojawiają się $\mathrm{w}$ ramach filozofii sztucznej inteligencji ${ }^{6}$. Projektanci takich systemów najczęściej nie próbują modelować w pełni inteligentnego systemu (silna sztuczna inteligencja), ale opracowują metody symulacji poszczególnych zdolności umysłowo-poznawczych człowieka (słaba sztuczna inteligencja), np.: percepcję i rozpoznawanie obrazów, rozwiązywanie problemów (m.in. wnioskowanie, podejmowanie decyzji, planowanie), przetwarzanie języka naturalnego, uczenie się, manipulacja i lokomocja ${ }^{7}$. Jednym z podstawowych paradygmatów badawczych dla konstrukcji słabej sztucznej inteligencji są modele inspirowane biologią ${ }^{8}$. W ich ramach, jak deklarują informatycy, naśladowanie natury pozwala na znajdowanie optymalnego rozwiązania problemu w przestrzeni stanów, w której znajdują się potencjalne rozwiązania danego problemu, a która to przestrzeń jest zbyt duża, aby zastosować nierandomizowane metody, np. symulację kognitywną9.

"Jest wiele utartych sposobów patrzenia na algorytmy ewolucyjne. Jedni widzą w nich metody sztucznej inteligencji, inni modele ewolucji i genetyki (»sztuczne życie«), jeszcze inni traktują je jako próbę rozwiązania zadania optymalizacji globalnej”” ${ }^{10}$. W ogólności algorytm ewolucyjny realizuje proces ciągłej adaptacji symulowanej populacji do wirtualnego środowiska. Nie można niestety zagwarantować, że wynikiem tego procesu będzie znalezienie najlepszego

6 Por. R. Murawski, Filozofia informatyki, Poznań 2014, 7-8, 149-174.

7 Por. M. Flasiński, Wstęp do sztucznej inteligencji, Warszawa 2011, 228-240.

8 Podstawowe koncepcje sztucznej inteligencji dzieli się na: symboliczną sztuczną inteligencję oraz inteligencję obliczeniową. Wśród tej ostatniej wyróżnia się: modele koncesjonistyczne (np. sztuczne sieci neuronowe), modele inspirowane matematyką (np. metody rozpoznawania obrazów) oraz modele inspirowane biologią (np. algorytmy ewolucyjne). Por. tamże, 3-31.

9 Por. tamże, 17-18.

10 J. Arabas, dz. cyt., 21. 
osobnika z możliwych. Jednakże przy pewnych założeniach można wykazać, że wraz z upływem czasu prawdopodobieństwo takiego wyniku wzrasta i dąży asymptotycznie do jedności ${ }^{11}$.

Algorytm ewolucyjny przetwarza populację osobników a każdy z nich jest propozycją rozwiązania postawionego i jednoznacznie zdefiniowanego problemu ${ }^{12}$. Działa on w wirtualnym środowisku, które definiuje się na podstawie postawionego problemu, który usiłuje się rozwiązać przy pomocy tego algorytmu. W tym cyfrowym środowisku każdemu wirtualnemu osobnikowi przyporządkowywana jest pewna wartość liczbowa, która określa jakość reprezentowanego przez niego rozwiązania. Wartość ta nazywana jest przystosowaniem osobnika do środowiska.

Każdemu wirtualnemu osobnikowi przyporządkowana jest informacja będąca jego genotypem. Na jej podstawie można w sposób jednoznaczny utworzyć fenotyp, tj. zestaw cech określanych przez genotyp, który podlega ocenie symulowanego środowiska. Wartość liczbowa tej oceny, to właśnie - wspomniane wyżej - przystosowanie osobnika. Innymi słowy, można powiedzieć, że w ramach algorytmów ewolucyjnych fenotyp kodowany jest przez genotyp (fenotyp jest punktem w przestrzeni rozwiązań danego problemu, a genotyp - punktem w przestrzeni kodów algorytmu ewolucyjnego).

Cyfrowe środowisko opisać można funkcją przystosowania. Za jej pomocą każdemu wirtualnemu osobnikowi można przypisać przystosowanie na podstawie jego fenotypu ${ }^{13}$. Ze względu na fakt, że

11 Por. tamże, 20.

12 Sposób działania algorytmów ewolucyjnych omawiam na podstawie: J. Arabas, dz. cyt., 15-17, M. Flasiński, dz. cyt., 58-72, L. Rutkowski, Metody i techniki sztucznej inteligencji, Warszawa 2011, 237-307.

13 „W przestrzeni genotypów funkcję przystosowania możemy sobie wyobrazić jako łańcuch wzgórz. Działanie algorytmu ewolucyjnego sprowadza się do premiowania takich osobników, które są lepiej przystosowane do środowiska, a zatem są położone bliżej wierzchołka jednego ze wzgórz". J. Arabas, dz. cyt., s. 17. 
fenotyp jest wynikiem kodowania genotypu, często przyjmuje się, że funkcja przystosowania określana jest dla genotypów.

Warto nadmienić, że genotyp danego osobnika składa się z chromosomów (najczęściej jeden osobnik zawiera jeden chromosom). Co najmniej jeden $\mathrm{z}$ chromosomów zawiera informacje kodujące fenotyp, a pozostałe chromosomy, o ile istnieją, mogą zawierać informacje potrzebne do prawidłowego działania algorytmu ewolucyjnego, lecz nie mają bezpośredniego wpływu na przystosowanie osobnika. Każdy z chromosomów natomiast składa się z genów.

Działanie algorytmu ewolucyjnego polega na wykonywaniu pętli, w której następują po sobie: reprodukcja (preselekcja), operacje genetyczne, ocena i sukcesja (postselekcja); czasem reprodukcję i sukcesję nazywa się selekcją. Zanim tak określona pętla cyfrowej ewolucji będzie mogła zadziałać, potrzebna jest faza inicjacji, która polega na utworzeniu początkowej populacji bazowej poprzez wygenerowanie genotypów osobników i obliczenie ich przystosowania. Proces ten jest najczęściej losowy.

Reprodukcja w połączeniu z operacjami genetycznymi modeluje wirtualne rozmnażanie, podczas którego materiał genetyczny cyfrowych rodziców jest przekazywany ich cyfrowym potomkom. Podczas reprodukcji zostają powielone osobniki z populacji bazowej. Warto dodać, że możliwe jest wielokrotne powielenie tego samego osobnika oraz to, że niektóre osobniki nie zostaną wybrane ani razu do powielenia. Wybór osobników do reprodukcji uwzględnia wartości przystosowania tych osobników, tj. te, które charakteryzują się większym przystosowaniem mają większe szanse powielenia.

Tak powstałe w wyniku reprodukcji kopie nazywane są osobnikami rodzicielskimi. Poddawane są one operacjom genetycznym (mutacji i krzyżowaniu), które w ogólności polegają na dokonywaniu losowych modyfikacji ich genotypów. Mutacja polega na niewielkiej zmianie genotypu jednego osobnika rodzicielskiego. Krzyżowanie (crossover) natomiast jest operatorem genetycznym, który działa na wielu osobnikach rodzicielskich (dwóch lub więcej). Ze względu na 
„wymieszanie” chromosomów wskutek krzyżowania operator ten jest często nazywany rekombinacją. Prowadzi on do wygenerowania jednego lub wielu osobników potomnych, których chromosomy powstają w wyniku, wspomnianego już, „wymieszania” chromosomów pochodzących od różnych wirtualnych rodziców. Warto nadmienić, że losowo wybiera się ile materiału genetycznego będzie pochodziło od poszczególnych wirtualnych rodziców (np. 30\% od jednego a 70\% od drugiego).

Osobniki utworzone w wyniku działania operatorów genetycznych tworzą populację potomną, która poddawana jest ocenie środowiska, po czym następuje sukcesja, w ramach której tworzy się nową populację bazową mogącą zawierać osobniki zarówno z populacji potomnej (wirtualne dzieci), jak i ze starej populacji bazowej (wirtualni rodzice).

Cykl tej cyfrowej ewolucji może zakończyć się wówczas, gdy przystosowanie osobników jest odpowiednio duże (założone uprzednio przez programistę), stwierdzi się, że stan populacji bazowej świadczy o stagnacji algorytmu (w kolejnych cyklach nie poprawia się przystosowanie osobników) lub algorytm ewolucyjny przeszedł zadaną z góry liczbę iteracji (cykli).

Warto dodać, że istnieją cztery najbardziej znane typy algorytmów ewolucyjnych: algorytmy genetyczne, strategie ewolucyjne, programowanie ewolucyjne i programowanie genetyczne.

Sposób działania algorytmów genetycznych jest najbardziej zbliżony do opisanego wyżej, ogólnego sposobu działania algorytmów ewolucyjnych ${ }^{14}$. We wstępnej fazie inicjujemy populację początkową osobników poprzez losowy wybór ustalonej liczby osobników. Dla każdego osobnika obliczamy wartość funkcji przystosowania (tj. przystosowanie), która określa jakość rozwiązania reprezentowanego

14 Szczegółowy opis algorytmów genetycznych znaleźć można w: J. Arabas, dz. cyt., 65-83, M. Flasiński, dz. cyt., 58-63, T. Gwiazda, Algorytmy genetyczne, Warszawa 1995, 7-21, L. Rutkowski, dz. cyt., 240-258. 
przez niego. Funkcja ta służy do wybrania (selekcji) najlepiej przystosowanych osobników w następnej fazie. Zbiór wyselekcjonowanych osobników stanowi populację rodzicielską, natomiast zbiór ich potomków nazywamy populacją potomków, którą uzyskujemy przez zastosowanie operatorów genetycznych: krzyżowania (z prawdopodobieństwem od 50 do $100 \%$ dwóch cyfrowych rodziców wydaje na świat dwóch cyfrowych potomków; miejsce przecięcia chromosomów rodziców jest wybierane losowo, zatem potomek nie musi posiadać po $50 \%$ genów od każdego z rodziców) i mutacji (z prawdopodobieństwem od 0 do $1 \%$ może zmieniać wartość pojedynczego genu z 0 na 1 lub odwrotnie). Po utworzeniu nowego pokolenia dokonujemy oceny populacji $\mathrm{w}$ analogiczny sposób do oceny populacji początkowej. Następnie sprawdzamy warunek zakończenia. Jeśli jest on spełniony, to przechodzimy do końcowej fazy algorytmu i wybieramy najlepszego (z największą wartością funkcji przystosowania) osobnika jako rozwiązanie postawionego problemu. Warunek ten może mieć różne postaci: zadaną z góry liczbę pokoleń, określony czas działania algorytmu, uzyskanie akceptowalnej jakości rozwiązania itp. Jeśli warunek zakończenia nie jest spełniony, to kontynuujemy cykl działania algorytmu genetycznego od fazy kolejnej selekcji osobników. Warto dodać, że każdy osobnik jest wyposażony w binarny (zero-jedynkowy) kod genetyczny. W wyniku działania mechanizmu selekcji i operatorów genetycznych średnia wartość przystosowania populacji ma tendencje wzrostowe a kolejnych rozwiązań poszukuje się w otoczeniu rozwiązań lepiej przystosowanych (co jest konsekwencją małego prawdopodobieństwa mutacji a dużego prawdopodobieństwa krzyżowania-rekombinacji).

Podstawowym wyróżnikiem strategii ewolucyjnych spośród pozostałych algorytmów ewolucyjnych jest mechanizm samoczynnej adaptacji zasięgu mutacji, tzn. algorytm wprowadza więcej mutacji, 
gdy nie poprawia się jakość znalezionych rozwiązañ ${ }^{15}$. Warto dodać, że w ramach strategii ewolucyjnych cyfrowy potomek może mieć więcej niż dwoje cyfrowych rodziców a ten sam osobnik może być dwoma cyfrowymi rodzicami danego potomka. Ponadto dobrze przystosowani rodzice mają szansę kolejnego cyfrowego życia, tj. przechodzą do populacji cyfrowych potomków (dobrze przystosowane osobniki mają możliwość cyfrowego życia przez wiele wirtualnych pokoleń). Warto także dodać, że strategie ewolucyjne nie są jednorodne, dzielą się na kilka podstawowych typów: $(1+1),(\mu+\lambda)$, $(\mu, \lambda)$. W strategii ewolucyjnej $(1+1)$ przetwarzany jest tylko jeden chromosom bazowy, który generuje jednego potomka i z tych dwóch cyfrowych organizmów do następnego pokolenia przechodzi osobnik $z$ większym przystosowaniem. $W$ strategii $(\mu+\lambda)$ przetwarzanych równolegle jest wiele chromosomów a do kolejnego pokolenia przechodzą najlepsze osobniki z populacji cyfrowych rodziców i potomków. Natomiast w strategii $(\mu, \lambda)$ kolejną populację tworzą najlepsze osobniki z populacji cyfrowych potomków (nie ma tutaj cyfrowej nieśmiertelności przez wiele pokoleń). Głównym zastosowaniem strategii ewolucyjnych jest konstruowanie optymalnych kształtów ciał w przepływach ${ }^{16}$.

W ramach programowania ewolucyjnego mamy do czynienia $\mathrm{z}$ innym poziomem abstrakcji w symulacji procesów ewolucji ${ }^{17}$. W algorytmach genetycznych i strategiach ewolucyjnych punkty przeszukiwania przestrzeni rozwiązań odpowiadają osobnikom danej populacji. Natomiast w przypadku programowania ewolucyjnego mamy do czynienia z metaforą gatunków. Ma to określone konsekwencje w konstrukcji samego algorytmu, gdyż np. nie występuje tutaj operacja krzyżowania (rekombinacji), gdyż nie zachodzi

15 Szczegółowy opis strategii ewolucyjnych znaleźć można w: J. Arabas, dz. cyt., 83-92, M. Flasiński, dz. cyt., 64-67, L. Rutkowski, dz. cyt., 258-274.

16 Por. M. Flasiński, dz. cyt., 64.

17 Szczegółowy opis programowania ewolucyjnego znaleźć można w: J. Arabas, dz. cyt., 92-96, M. Flasiński, dz. cyt., 67-69, L. Rutkowski, dz. cyt., 274. 
ona pomiędzy gatunkami. Nie zakłada się również jakiejś formy reprezentacji osobników, która powinna być adekwatna w stosunku do danego problemu ${ }^{18}$.

W programowaniu genetycznym natomiast zamiast przeszukiwać przestrzeń rozwiązań za pomocą programu opartego na zasadach teorii ewolucji, tworzy się populację programów i przeszukuje się przestrzeń możliwych programów w celu znalezienia najlepszego (w kontekście zakładanego celu, który chcemy osiągnąć w ramach tej metody $)^{19}$. Zadanie programowania genetycznego zostało pierwotnie określone jako automatyczna synteza programu komputerowego rozwiązującego zdefiniowany problem ${ }^{20}$. Warto dodać, że w ogólności terminu programowanie genetyczne używa się do określenia algorytmów ewolucyjnych wykorzystujących drzewiastą reprezentację zadania i modyfikujących, w toku cyfrowej ewolucji, strukturę tej reprezentacji. Podstawowym operatorem genetycznym jest tutaj krzyżowanie (sensownych rozwiązań), natomiast mutacja pełni drugorzędną rolę.

18 „Ze względu na możliwość określenia różnych form reprezentacji rozliczne zastosowania programowania ewolucyjnego obejmują tak różnorodne zagadnienia, jak m.in.: konstrukcja systemów sterowania, opracowywanie farmaceutyków, sterowanie urządzeniami elektroenergetyki, diagnostyka chorób nowotworowych, przetwarzanie sygnałów. W sztucznej inteligencji programowanie ewolucyjne jest wykorzystywane nie tylko w zagadnieniach rozwiązywania problemów (głównie: optymalizacyjnych i kombinatorycznych), ale również w obszarze systemów uczących się". M. Flasiński, dz. cyt., 69.

19 Szczegółowy opis programowania genetycznego znaleźć można w: J. Arabas, dz. cyt., 96-100, M. Flasiński, dz. cyt., 70-72, L. Rutkowski, dz. cyt., 274-276.

20 „Tak postawione zadanie rozszerzono następnie na inne (oprócz programów komputerowych) systemy projektowane w naukach technicznych, jak układy cyfrowe (w elektronice) czy też regulatory (w automatyce)". M. Flasiński, dz. cyt., 70. 


\section{PODSTAWOWE IDEE BIOLOGII EWOLUCYJNEJ ZAIMPLEMENTOWANE W ALGORYTMACH EWOLUCYJNYCH}

Inspiracją do podjęcia badań dotyczących algorytmów ewolucyjnych, jak twierdzą osoby zajmujące się tą problematyką, było naśladowanie natury. „Algorytm ewolucyjny stanowi wzorowaną na naturalnej ewolucji metodę rozwiązywania problemów, głównie zagadnień optymalizacyjnych. Algorytmy ewolucyjne są procedurami przeszukiwania opartymi na mechanizmach doboru naturalnego i dziedziczenia. Korzystają z ewolucyjnej zasady przeżycia osobników najlepiej przystosowanych"21.

Opis algorytmów ewolucyjnych zaprezentowany w poprzednim rozdziale ujawnił, że korzystają one z określeń zapożyczonych z biologii ewolucyjnej i genetyki. Mówiąc o tych algorytmach nie da się uniknąć takich pojęć, jak: osobnik (reprezentant rozwiązania problemu, punkt w przestrzeni poszukiwań), populacja (zbiór osobników w przestrzeni rozwiązań), chromosom (uporządkowane ciągi genów, ciągi kodowe), gen (pojedyncza cecha rozwiązania problemu, pojedynczy element genotypu), genotyp (współrzędne osobnika w przestrzeni potencjalnych rozwiązań; genotyp jest zazwyczaj jednochromosomowy, zatem osobnik to genotyp lub chromosom), fenotyp (zestaw wartości odpowiadających danemu genotypowi, konkretna wartość współrzędnych rozważanego problemu, zakodowana struktura rozwiązania), mutacja (zmiana wartości pojedynczego genu na przeciwną), krzyżowanie (wymiana losowej długości

21 L. Rutkowski, dz. cyt., 238. 
odcinków chromosomów) ${ }^{22}$, pokolenie (kolejna iteracja w algorytmie genetycznym) $)^{23}$.

„Terminologia, którą się posługujemy, nazywając elementy algorytmów genetycznych, jest dość specyficzna, powstała bowiem wskutek inspiracji genetyką i ewolucją" ${ }^{24}$. Jak się jednak wydaje, transfer idei z biologii ewolucyjnej do informatyki w zakresie bazy pojęciowej był dość powierzchowny. Pojęcia używane w ramach algorytmów ewolucyjnych brzmią dokładnie tak samo jak w biologii ewolucyjnej, lecz często ich znaczenie jest inne. Najłatwiej można prześledzić to na przykładzie, scharakteryzowanego wyżej, pojęcia „krzyżowanie”. W ramach algorytmów ewolucyjnych oznacza ono wymianę losowej długości odcinków chromosomów. W ramach biologii ewolucyjnej używanemu w informatyce pojęciu krzyżowanie odpowiada pojęcie „rekombinacja”, w ramach której u osobników płciowych podczas rozmnażania następuje wymiana połowy chromosomów. Zatem w przypadku algorytmów genetycznych wirtualni rodzice wnoszą do organizmu wirtualnego potomka po losowej części chromosomów (np. 25\% chromosomów od wirtualnego rodzica A i 75\% od wirtualnego rodzica B) a w przypadku rozmnażania biologicznego rodzice wnoszą po połowie chromosomów do organizmu swojego potomka (50\% chromosomów od rodzica A i 50\% od rodzica B).

Warto także podkreślić, że omówione w poprzednim rozdziale cztery podstawowe rodzaje algorytmów genetycznych w znacznej mierze różnią się między sobą, m.in. sposobem reprezentacji osobników, rolą odgrywaną przez operatory genetyczne oraz sposobem

22 Ze względu na „wymieszanie” chromosomów wskutek krzyżowania operator ten jest często nazywany rekombinacją. „Termin krzyżowanie przyjął się w języku polskim jako odpowiednik angielskiego terminu crossover. Zdaniem autora polski termin jest niefortunny, gdyż w biologii terminu krzyżowanie używa się w odniesieniu do gatunków, odmian czy ras, natomiast proces molekularny zachodzący podczas rozmnażania płciowego, modelowany w algorytmach ewolucyjnych, określany jest nazwą krosowania”. J. Arabas, dz. cyt., 17.

23 Por. L. Rutkowski, dz. cyt., 239-240.

24 J. Arabas, dz. cyt., 15. 
tworzenia nowej populacji (przedstawiono to w syntetyczny sposób $\mathrm{w}$ tabeli 1). W ramach algorytmów genetycznych mamy do czynienia z kodowaniem binarnym (zero-jedynkowym) osobników. W ramach strategii ewolucyjnych osobniki kodowane są przez wektory liczb rzeczywistych. W programowaniu ewolucyjnym w ogóle nie mamy do czynienia $\mathrm{z}$ kodowaniem osobników, gdyż algorytmy tego typu przeprowadzają wirtualną ewolucję na poziomie populacji. W programowaniu genetycznym natomiast mamy reprezentacje drzewiaste osobników. Widać zatem, że są to różnice zasadnicze, a zatem algorytmy ewolucyjne nie są jednorodne pod względem kodowania, tj. sposobu reprezentacji osobników. Wpływa to z pewnością na możliwości uzyskiwania kreślonych klas wyników, a również na to, że algorytmy ewolucyjne różnią się $\mathrm{w}$ tym zakresie od kodowania dostępnego w świecie przyrody ożywionej, gdzie materiałem genetycznym jest DNA (kodowanie informacji genetycznej osobnika zachodzi przy pomocy 4 ,liter”: A, G, C, T).

W ramach algorytmów genetycznych i programowania genetycznego zasadniczą rolę odgrywa operator genetyczny krzyżowania (rekombinacji). W strategiach ewolucyjnych natomiast podstawowe są mutacje. W programowaniu ewolucyjnym obecne w procesie wirtualnej ewolucji są jedynie mutacje, gdyż gatunki (tj. podstawowy „osobnik” w ramach programowania ewolucyjnego) nie są poddawane rekombinacji. W ewolucji biologicznej natomiast podstawowym procesem, który ma udział w zmienności genetycznej jest rekombinacja, czyli wymiana fragmentów chromosomów w dzielących się komórkach zachodząca zawsze w procesie mejozy. Widać zatem, że w kontekście roli odgrywanej przez operatory genetyczne, algorytmy genetyczne i programowanie genetyczne są najbliżej naturalnych procesów ewolucji biologicznej (w ramach organizmów płciowych), a strategie ewolucyjne i programowanie ewolucyjne w znacznym stopniu od niej odbiegają.

Z podobnymi rozbieżnościami mamy do czynienia w przypadku mutacji, która jest drugoplanowa dla algorytmów genetycznych 


\begin{tabular}{|c|c|c|c|c|c|}
\hline 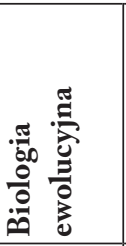 & $\begin{array}{l}1 \\
0 \\
0 \\
i \\
i\end{array}$ & 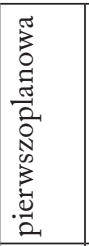 & 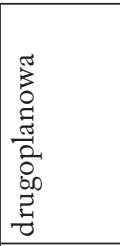 & 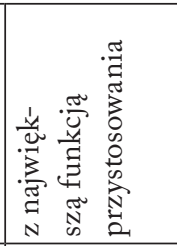 & 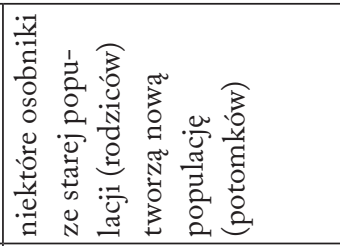 \\
\hline 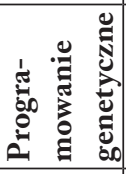 & 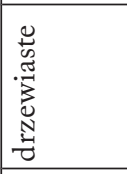 & 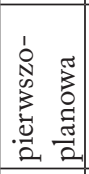 & 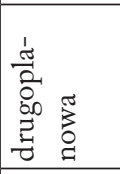 & 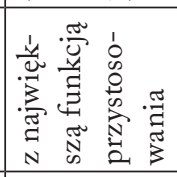 & 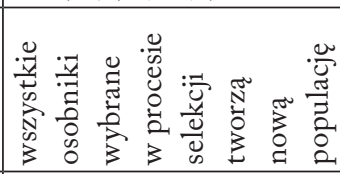 \\
\hline 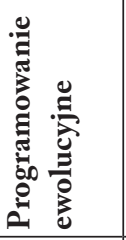 & 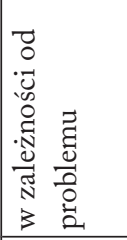 & 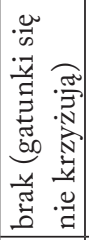 & 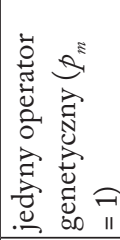 & 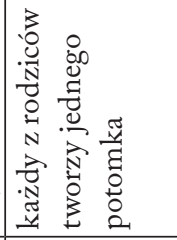 & 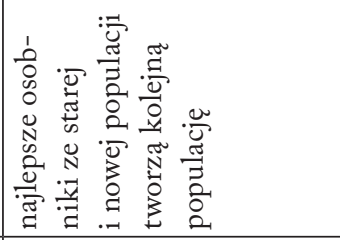 \\
\hline 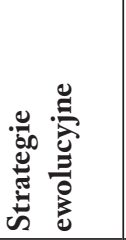 & 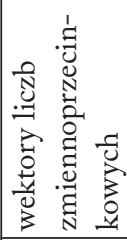 & 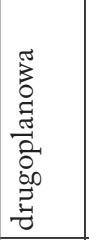 & 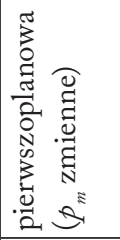 & 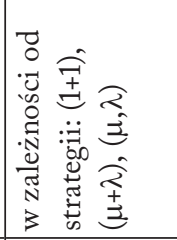 & 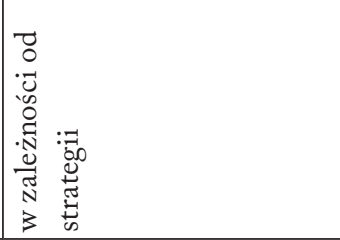 \\
\hline \multirow[t]{2}{*}{ 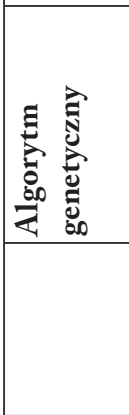 } & 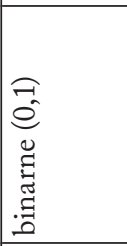 & 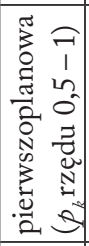 & 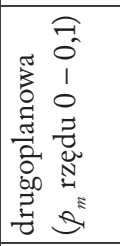 & 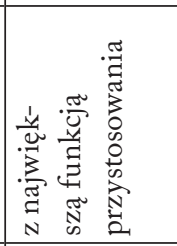 & 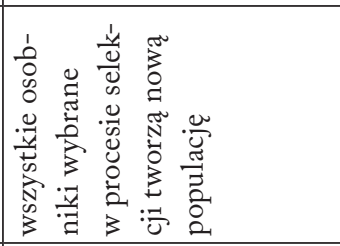 \\
\hline & 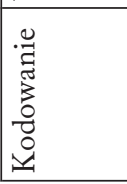 & 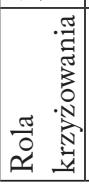 & 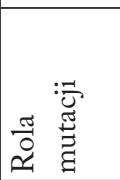 & $\begin{array}{ll} & 3 \\
0 & 0 \\
0 & 0 \\
0 & 0 \\
0 & 0 \\
0 & 0 \\
0 & 0\end{array}$ & 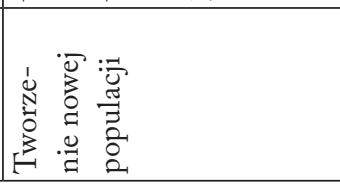 \\
\hline
\end{tabular}

Tabela 1. Idee biologii ewolucyjnej w algorytmach ewolucyjnych (opracowanie własne $\left.{ }^{25}\right)$.

25 Opracowanie na podstawie: L. Rutkowski, Metody i techniki sztucznej inteligencji, dz.cyt., 306. 
i programowania genetycznego, pierwszoplanowa dla strategii ewolucyjnych a jest jedynym operatorem genetycznym dla programowania ewolucyjnego. Mutacje w procesie ewolucji biologicznej prowadzą do zwiększenia różnorodności puli genów w populacji. Nie stanowią one wystarczającej przyczyny ewolucji, lecz wraz z mającymi zdecydowanie szerszy zasięg rekombinacjami są podstawowym źródłem zmienności. Tak więc, podobnie jak w przypadku rekombinacji, tak również w przypadku mutacji, rola tego operatora genetycznego zbliża algorytmy genetyczne i programowanie genetyczne do procesów ewolucji biologicznej. Strategie ewolucyjne i programowanie ewolucyjne odbiegają od naturalnych procesów, gdyż w przyrodzie nie obserwuje się 100\% prawdopodobieństwa mutacji (programowanie ewolucyjne) lub zmiany prawdopodobieństwa mutacji w zależności od szybkości ewolucji (strategie ewolucyjne zawierają mechanizm samoczynnej adaptacji zasięgu mutacji, tzn. algorytm ten wprowadza więcej mutacji, gdy nie poprawia się jakość znalezionych rozwiązań).

Dobór rodziców przebiega znowu w przypadku algorytmów genetycznych i programowania genetycznego w sposób analogiczny do procesów ewolucji biologicznej (najlepiej przystosowane do danego środowiska osobniki mają największe szanse stać się rodzicami). W przypadku natomiast strategii ewolucyjnych i programowania ewolucyjnego odbywa się to inaczej niż podczas naturalnych procesów biologicznych (istnieją różne strategie doboru rodziców w ramach strategii ewolucyjnych a każdy organizm z populacji bieżącej tworzy jednego potomka w populacji potomnej w ramach programowania ewolucyjnego).

W przypadku natomiast sposobu tworzenia nowej populacji (potomnej) wszystkie rodzaje algorytmów ewolucyjnych odbiegają od procesów opisywanych w ramach biologii ewolucyjnej. W ramach algorytmów genetycznych i programowania genetycznego wszystkie osobniki wybrane w procesie selekcji tworzą nową populację (wszystkie organizmy, które przeżyły w walce o wirtualny byt się rozmnażają) a w ramach strategii ewolucyjnej i programowania ewolucyjnego 
możliwe są scenariusze, $\mathrm{w}$ ramach których najlepsze osobniki ze starej i nowej populacji tworzą koleje pokolenie (możliwy jest transfer najlepszych wirtualnych rodziców bezpośrednio do pokolenia wirtualnych dzieci, tzn. możliwe jest wirtualne życie przez wiele pokoleń, tj. wielopokoleniowa wirtualna nieśmiertelność). Oczywistym jest, że w ramach ewolucji biologicznej nie mamy do czynienia z przypadkami, że wszystkie osobniki z danego pokolenia stają się rodzicami (tylko niektóre osobniki ze starej populacji rodziców tworzą nową populację potomków) oraz z nieśmiertelnością przez wiele pokoleń (każdy organizm biologiczny umiera w skończonym czasie).

Istnieją także znaczące podobieństwa algorytmów genetycznych do procesów opisywanych w ramach biologii ewolucyjnej. Mamy bowiem do czynienia ze znaczącą rolą selekcji w rozwiązywaniu problemów (w ramach algorytmów genetycznych, strategii ewolucyjnych oraz programowania genetycznego) oraz rolą doboru naturalnego, który jest odpowiednikiem selekcji w ramach algorytmów ewolucyjnych, podczas biologicznej ewolucji organizmów żywych. Widać także znaczącą rolę operatorów genetycznych (krzyżowania i mutacji) przy rozwiązywaniu problemów (w ramach algorytmów genetycznych i programowania genetycznego) oraz znaczącą rolą rekombinacji i mutacji podczas ewolucji biologicznej. Algorytmy ewolucyjne realizują proces ciągłej adaptacji wirtualnej populacji do zdefiniowanego środowiska (niezmiennego w czasie), a w przyrodzie ożywionej mamy także do czynienia z procesem ciągłej adaptacji populacji do środowiska biologicznego (zmiennego w czasie). W wypadku powyższych podobieństw można z pewnością mówić o transferze idei z biologii ewolucyjnej do informatyki.

W przypadku natomiast, wymienionych $\mathrm{w}$ tabeli 2 , różnic zachodzących między algorytmami ewolucyjnymi a biologią ewolucyjną, możemy co najwyżej mówić o transferze pewnych ogólnych pojęć biologicznych do informatyki, gdzie zostały one w dużym stopniu zinterpretowane dość dowolnie częstokroć tracąc swoje podstawowe biologiczne znaczenie. Widoczne jest to najwyraźniej w procedurach 
teleologicznego sterowania wirtualną ewolucją za pomocą: samoczynnej adaptacji zasięgu mutacji (w ramach strategii ewolucyjnych i programowania ewolucyjnego), adaptacji wirtualnej populacji do ściśle zdefiniowanego, niezmiennego środowiska, które wyznacza cel wirtualnej ewolucji, projektowania przestrzeni stanów przypominającego projektowanie świata przez inteligentnego projektanta $\mathrm{w}$ ramach koncepcji inteligentnego projektu.

\begin{tabular}{|l|l|}
\hline Algorytmy ewolucyjne & Biologia ewolucyjna \\
\hline $\begin{array}{l}\text { Samoczynna adaptacja zasięgu mutacji } \\
\text { (SE, PE) }\end{array}$ & $\begin{array}{l}\text { Quasi-losowy (raczej stały) zasięg } \\
\text { mutacji }\end{array}$ \\
\hline $\begin{array}{l}\text { Stała liczba osobników w populacji } \\
\text { (AG) }\end{array}$ & Zmienna liczba osobników w populacji \\
\hline Określona liczba pokoleń & Nieokreślona liczba pokoleń \\
\hline $\begin{array}{l}\text { Arbitralnie wyznaczony koniec } \\
\text { ewolucji” }\end{array}$ & Brak arbitralnego końca ewolucji \\
\hline $\begin{array}{l}\text { Działają w środowisku niezmiennym } \\
\text { w czasie }\end{array}$ & $\begin{array}{l}\text { Odbywa się w środowisku zmiennym } \\
\text { w czasie }\end{array}$ \\
\hline $\begin{array}{l}\text { Każdorazowo wymagają etapu kon- } \\
\text { strukcji modelu opisu problemu (kon- } \\
\text { strukcji przestrzeni stanów) }\end{array}$ & $\begin{array}{l}\text { Nie istnieje coś takiego (tego typu } \\
\text { procedura zakładana jest np. przez zwo- } \\
\text { lenników teorii inteligentnego projektu) }\end{array}$ \\
\hline $\begin{array}{l}\text { Teleologiczne (osiągnięcie zakładanego } \\
\text { celu - adaptacja do niezmiennego, jed- } \\
\text { noznacznie określonego, środowiska) }\end{array}$ & $\begin{array}{l}\text { Teleonomiczna (adaptacja do nieustan- } \\
\text { nie zmieniającego się środowiska) }\end{array}$ \\
\hline
\end{tabular}

Tabela 2. Podstawowe różnice między algorytmami ewolucyjnymi a biologią ewolucyjną (opracowanie własne).

Z przedstawionej treści niniejszego rozdziału wyraźnie widać, że różnic pomiędzy algorytmami ewolucyjnymi a biologią ewolucyjną jest znacznie więcej niż, opisanych wyżej, podobieństw. Warto jeszcze raz podkreślić także i to, że między różnymi rodzajami algorytmów ewolucyjnych zachodzą zasadnicze różnice a wspólny schemat ich działania, opisany w poprzednim rozdziale, $z$ racji wzmiankowanych różnic mógł zostać zaprezentowany tylko w bardzo wysokim stopniu 
ogólności. Przeprowadzone analizy pozwalają jednak na udzielenie odpowiedzi na pytania zawarte we wstępnej części tekstu. Poświęcona zostanie temu ostatnia część prezentowanego artykułu.

\section{PODSUMOWANIE}

Algorytmy ewolucyjne są ważne dla epistemologii, ponieważ przy ich pomocy można podejmować udane próby komputerowego symulowania sposobów dochodzenia do wiedzy i jej rozwoju postulowane przez epistemologie ewolucyjne (w stylu Poppera). Ponadto są także bardzo ważne dla biologii, gdyż w trybie symulacyjnym pozwalają testować postulaty teorii ewolucji, tzn. czy mutacje i rekombinacje osobników mogą prowadzić do zmienności, która pozwala im być lepiej przystosowanymi do danego środowiska ${ }^{26}$. Oczywiście tego typu wirtualne testy można przeprowadzać lepiej lub gorzej.

Niewątpliwie dość kiepskim przykładem zastosowania symulacji komputerowych do testowania postulatów teorii ewolucji są próby Dawkinsa opisane w Ślepym zegarmistrzu, gdzie m.in. przy ich pomocy próbuje argumentować na rzecz tezy, że świat nie został celowo zaprojektowany. Jego argumentacja jest przynajmniej z dwóch powodów chybiona. Po pierwsze, żaden z algorytmów ewolucyjnych (a także program autora Samolubnego genu) nie symuluje dokładnie procesu ewolucji biologicznej. Różne rodzaje algorytmów ewolucyjnych symulują różne aspekty procesu ewolucji a w tym zakresie program Dawkinsa jest najsłabszy, gdyż to sam autor Fenotypu rozszerzonego był subiektywną instancją selekcjonującą organizmy, które nie były kasowane i mogły się wirtualnie rozmnażać (w algorytmach genetycznych rolę tę pełni funkcja przystosowania do zdefiniowanego środowiska). Po drugie, algorytmy genetyczne są pośrednio sterowane (adaptacja do zaprojektowanego środowiska) przez inteligentnego projektanta (informatyka). Algorytm Dawkinsa, co warto podkreślić,

26 Por. S. Leciejewski, dz. cyt., 263-273. 
jest nawet bezpośrednio sterowany przez samego autora dokonującego selekcji sztucznych zwierząt na podstawie subiektywnych kryteriów estetycznych. W ten sposób można co najwyżej symulować teleologiczną ewolucję w ramach niektórych koncepcji inteligentnego projektu, a z pewnością nie o to autorowi Boga urojonego chodziło ${ }^{27}$.

$\mathrm{Na}$ podstawie przedstawionych w poprzednim rozdziale analiz można twierdzić, że ustalenia biologii ewolucyjnej były inspiracją do powstania algorytmów ewolucyjnych. Jest to najlepiej widoczne na przykładzie: selekcji, krzyżowania, mutacji i adaptacji, które zostały wcześniej szczegółowo omówione.

Tak więc mial miejsce transfer idei z biologii do informatyki, co jest najlepiej widoczne w ramach algorytmów genetycznych i programowania genetycznego, których sposób działania w znacznym stopniu jest wzorowany na procesach opisywanych przez biologię ewolucyjną.

Warto jednak podkreślić, że transfer idei z biologii do informatyki był częściowy i wybiórczy. Niektóre rodzaje algorytmów ewolucyjnych działają w sposób znacznie odbiegający od ewolucji biologicznej. Mamy na przykład do czynienia z pierwszoplanową rolą mutacji i możliwym życiem przez wiele pokoleń w ramach strategii ewolucyjnych. Nie istnieje, jakże ważna z biologicznego punktu widzenia, rekombinacja $\mathrm{w}$ ramach programowania ewolucyjnego. Natomiast teleologia, obca naturalistycznie nastawionej biologii ewolucyjnej, jest zaimplementowana we wszystkich czterech rodzajach algorytmów ewolucyjnych ${ }^{28}$.

Procesy cyfrowej ewolucji w ramach omawianych algorytmów ewolucyjnych zachodzą dzięki „operacjom analogicznym do tych, jakie mają miejsce w przypadku organizmów żywych, na przykład

27 Por. H.D. Mutschler, Wprowadzenie do filozofii przyrody, Kraków 2005, 145.

28 „Cała maszyneria 'genetycznych algorytmów' pozwala się np. tylko wtedy użyć, gdy 'funkcję fitness' potraktujemy jako coś zastępującego jakiś cel. W przeciwnym razie nie można zrozumieć wywołanego przez nią przebiegu optymalizacji”. Tamże, 146. 
mutacjom oraz/lub krzyżowaniu rozwiązań-osobników”29. Tak więc między procesem ewolucji biologicznej a procesami cyfrowej ewolucji w ramach algorytmów ewolucyjnych możemy co najwyżej mówić o pewnych, bliższych lub dalszych, analogiach. Bliższe będą w ramach algorytmów genetycznych i programowania genetycznego, a niewątpliwie dalsze - $w$ ramach strategii ewolucyjnych i programowania ewolucyjnego (por. tabela 1).

Zdaje się jednak, że idea ewolucji biologicznej jest jednym z ważniejszych schematów wyjaśniania zagadnienia rozwiązywania problemów $\mathrm{w}$ informatyce symulowanego $\mathrm{w}$ ramach algorytmów ewolucyjnych (słabej sztucznej inteligencji). Jest to z pewnością dziedzina wiedzy, która w przyszłości będzie dostarczyła wielu ciekawych wyników naukowych i zapraszała do refleksji filozoficznych o charakterze ontologicznym i epistemologicznym. „Modele organizmów żywych i ich procesów fizjologicznych, mechanizmy ewolucyjne i ekologiczne stanowić będą niewyczerpane źródło inspiracji konstrukcji efektywnych metod rozwiązywania problemów ogólnych”30.

\section{BIBLIOGRAFIA}

Arabas J., Wyktady z algorytmów erwolucyjnych, Wydawnictwa Naukowo-Techniczne, Warszawa 2004.

Czarnocka M., Podmiotpoznania a nauka, Wydawnictwo Naukowe Uniwersytetu Mikołaja Kopernika, Toruń 2012.

Flasiński M., Wstęp do sztucznej inteligencji, Wydawnictwo Naukowe PWN, Warszawa 2011.

Gwiazda T., Algorytmy genetyczne, „T.D.G.” S.cyw., Warszawa 1995.

Leciejewski S., Ewolucyjna teoria epistemologiczna metoda algorytmów genetycznych, Przegląd Filozoficzny - Nowa Seria 23(2014)4(92), 262-273.

Michalewicz Z., Algorytmy genetyczne + struktury danych = programy erwolucyjne, Wydawnictwa Naukowo-Techniczne, Warszawa 1999.

29 M. Flasiński, dz. cyt., 30.

30 Tamże, 252. 
Filozofia informatyki, red. R. Murawski, Wydawnictwo Naukowe UAM, Poznań 2014.

Mutschler H.D., Wprowadzenie do flozofii przyrody, Wydawnictwo WAM, Kraków 2005.

Rutkowski L., Metody i techniki sztucznej inteligencji, Wydawnictwo Naukowe PWN, Warszawa 2011.

\title{
KNOWLEDGE TRANSFER FROM BIOLOGY TO COMPUTER SCIENCE ON THE EXAMPLE OF EVOLUTIONARY ALGORITHMS
}

\begin{abstract}
IT specialists engaged in the issues of evolutionary algorithms claim that there has been a transfer of knowledge from biology to computer science, i.e., certain findings in evolutionary biology have become an inspiration for the creation of algorithms whose function is analogous to that of naturally occurring evolutionary processes. If this is correct, the following question should beanswered: what is the extent of knowledge transfer from evolutionary biology to computer science dealing with evolutionary algorithms? Answering this question becomes possible after a prior review of the working mode of evolutionary algorithms.
\end{abstract}

Keywords: philosophy of computer science, artificial intelligence, evolutionism, evolutionary biology, evolutionary algorithms

\footnotetext{
SŁAWOMIR LECIEJEWSKI

slaaw@amu.edu.pl

Uniwersytet im. Adama Mickiewicza w Poznaniu, Instytut Filozofii

Szamarzewskiego 89c, 60-569 Poznań
}

DOI: 10.21697/spch.2017.53.1.12 